\title{
Rangkaian Penyearah RF ke DC Bertingkat untuk Multi Frekuensi Kerja pada Sistem Pengisian Listrik Secara Nirkabel
}

\section{RF to DC Rectifier Multi Stage Circuit for Multiple Operation Frequencies in Wireless Electrical Charging Systems}

\author{
Budi Herdiana*, Heroe Wijanto, dan Iswahyudi Hidayat \\ Program Studi Teknik Elektro Pascasarjana, Fakultas Teknik Elektro, Universitas Telkom \\ Jl. Telekomunikasi No. 1 Bojongsoang Bandung, 40257
}

\begin{abstract}
Abstrak
Energi berkesinambungan untuk perangkat elektronik bergerak selalu dibutuhkan selama kapasitas penyimpanan energi dari baterai di perangkat elektronik bergerak tersebut terbatas untuk beberapa jam waktu pemakaian saja. Untuk mendapatkan waktu operasi yang panjang dari perangkat elektronik bergerak, sumber energi seharusnya dihubungkan selalu ke perangkat tersebut. Pada makalah ini, kami mengajukan metode pengisian energi melalui operasi nirkabel menggunakan gelombang mikro (RF) yang diradiasikan dengan multi frekuensi kerja di udara. Rangkaian penyearah dari RF ke DC merupakan komponen utama untuk mengubah gelombang RF ke arus elektronik (DC). Model Dickson digunakan sebagai pendekatan dengan keuggulannya antara lain rangkaian yang sederhana, faktor ripple DC yang rendah, dan lain lain. Desain, analisis, dan eksperimen dari rangkaian penyearah tersebut telah dilakukan dan dipaparkan pada makalah ini. Pada pengukuran, perangkat elektronik bergerak diletakkan dengan jarak sekitar 5 meter dari sumber energi, tegangan DC sebesar 3,7 V telah diperoleh pada frekuensi kerja 825-960 MHz dengan nilai PCE $12-33 \%$ dan faktor ripple sebesar $\pm 0.01 \%$. Waktu pengisian energi sekitar 4 jam pada ruang percobaan dan sekitar 11 jam di luar ruangan telah diobservasi. Berdasarkan hasil tersebut, metode pengisian energi secara nirkabel untuk perangkat elektronik bergerak merupakan kandidat yang potensial untuk menyelesaikan masalah energi berkesinambungan dan mendukung sebagian program teknologi hijau.
\end{abstract}

Kata kunci: pengisian energi nirkabel, rangkaian penyearah RF ke DC, model Dickson, energi berkesinambungan.

\section{Abstract}

Sustainable energy for mobile devices is always required since power capacity of a battery in the mobile devices is limited for a few hour operation times only. In order to obtain long operation time of the mobile devices, energy/power sources should be connected always to them. In this paper, we propose power charging methods with wireless operation using radiated microwave signals with multiple microwave frequencies in the air. $R F$ to DC rectifiers are the key components for converting the radiated microwave signals $(R F)$ to electronic currents $(D C)$. Dickson model is used in this approach with its advantages such as simple circuit, small DC ripple factor, etc. Design, analysis, and experiment of the rectifier were done and reported in this paper. In measurement, the mobile devices are located about 5 meters distance to the power sources. As a result, DC voltage of $3.7 \mathrm{~V}$ was obtained in $825-960 \mathrm{MHz}$ operational frequency with PCE value of 12-33\% and ripple factor of $\pm 0.01 \%$. Power charging time of \pm 5 hours in the experimental room and \pm 11 hours in the outdoor were observed. Based on the results, wireless power charging methods to the mobile devices are potential candidate to solve the sustainable energy problem and also partly supporting the green technology program.

Keywords: wireless power charging, RF to DC rectifier, Dickson model, sustainable energy.

\section{Pendahuluan}

Meningkatnya jumlah pemakaian perangkat telepon seluler saat ini menyebabkan ketersediaan energi catuan bagi perangkat telekomunikasi tersebut menjadi keharusan agar komunikasi tetap berjalan. Sumber energi pencatuan selama ini hanya mengandalkan pada sumber energi jala-jala listrik AC $220 \mathrm{~V}$ yang juga memiliki beberapa keterbatasan terutama ketika kita berada pada posisi jauh dari sumber energi jala-jala

\footnotetext{
* Corresponding Author.

Email: budiherdiana77@gmail.com

Received: September 2, 2014; Revised: October 31, 2014

Accepted: November 4, 2014

Published: December 30, 2014

(c) 2014 PPET - LIPI

doi : $10.14203 /$ jet/v14.40-44
}

listrik tersebut karena kebiasaan pemakai ponsel selalu memilki mobilitas tinggi sedangkan konsistensi kebutuhan energi catuan selalu harus tetap terpenuhi. Karena itu untuk mengurangi keterbatasan itu, maka diperlukan sumber energi lain yang bisa dijadikan energi alternatif seperti gelombang elektromagnetik, solar cell, dan lain-lain. Sumber energi alternatif tersebut yang mudah diperoleh tentu salah satunya adalah energi RF di mana ketersediaannya cukup melimpah di sekitar kita misalnya energi RF berasal dari BTS, access point (Wi-Fi) atau ISM Band. Pada dasarnya tegangan catuan yang diperoleh dari sumber energi RF akan bernilai kecil karena karakteristik daya RF sendiri saat terdeteksi sangat kecil seiring meningkatnya rugi-rugi transmisi terhadap jarak pancar. Karena itu jika menginginkan tegangan catuan sesuai 
perangkat yang akan dicatu, maka diperlukan model penyearah yang memiliki kemampuan mengubah energi RF ke DC sekaligus memiliki kemampuan menguatkan tegangan ke level tegangan catuan guna mendukung terwujudnya perangkat catu daya [1], [2]. Pada makalah ini akan digambarkan struktur rancangan rangkaian penyearah energi RF secara bertingkat multi frekuensi untuk diterapkan pada catu daya berdaya rendah sebagai sebuah sistem charger ponsel menggunakan pendekatan modifikasi model Dickson (Dickson's models) di mana dioda schottky HSMS2822 sebagai komponen utama penyearahnya.

\section{Konsep Rangkaian Penyearah RF}

Teknologi power transfer wireless dapat dijadikan sebagai sumber catuan alternatif bagi perangkat telepon seluler ketika sumber daya catuan yang ada memiliki keterbatasan dalam menyediakan energi secara berkesinambungan. Salah satu penerapan teknologi ini adalah $R F$ to DC Converter yang merupakan sistem penyearah energi gelombang elektromagnetik RF menjadi energi DC. Sistem penyearah ini dibangun oleh dua komponen utama yaitu antena sebagai penangkap energi RF di ruang bebas dan penyearah sebagai pengubah gelombang RF menjadi DC. Tahapan penyearahannya ditunjukan seperti pada Gambar 1 berikut ini:

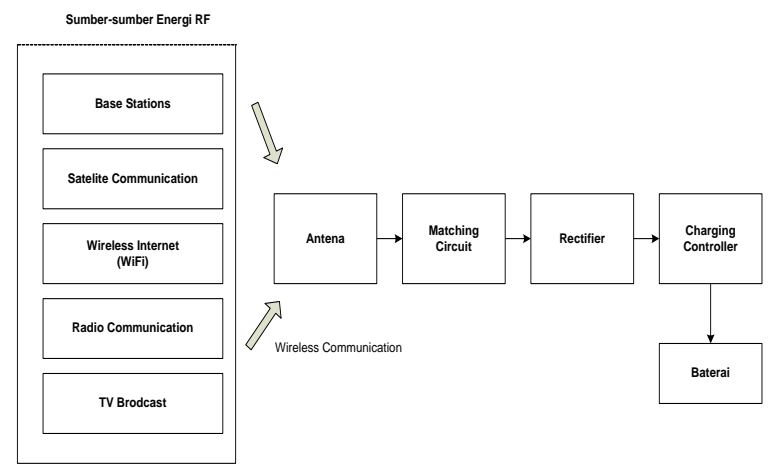

Gambar 1. Sistem Penyearah Gelombang RF ke DC [3], [4].

Karakterisasi sistem penyearah energi RF multi frekuensi seperti pada gambar 1 di atas dapat dianalisis berdasarkan daya rata-rata yang diterima secara simultan dimana besarnya dirumuskan sebesar [3]:

$$
\mathrm{P}_{\mathrm{RF}}(\mathrm{t})=\frac{1}{\mathrm{f}_{\text {high }}-\mathrm{f}_{\text {low }}} \int_{\mathrm{f}_{\text {low }}}^{\mathrm{f}_{\text {high }}} \int_{0}^{4 \pi} \mathrm{S}(\theta, \varphi, \mathrm{f}, \mathrm{t}) \mathrm{A}_{\mathrm{eff}(\theta, \varphi, \mathrm{f})} \mathrm{d} \Omega \mathrm{df}
$$

Untuk frekuensi ke-i dengan daya masukan ke-i diperoleh daya DC sebesar:

$$
\mathrm{P}_{\mathrm{DC}}\left(\mathrm{f}_{\mathrm{i}}\right)=\mathrm{P}_{\mathrm{RF}}\left(\mathrm{f}_{\mathrm{i}}, \mathrm{t}\right) \eta\left[\mathrm{P}_{\mathrm{RF}}\left(\mathrm{f}_{\mathrm{i}}, \mathrm{t}\right), \rho, \mathrm{Z}_{\mathrm{DC}}\right]
$$

Sedangkan daya DC dari masukan berbagai sumber daya RF multi frekuensi merupakan resultan dari penguatan antena penerima dan daya RF ke-i yang diterima dinyatakan sebesar [1]:

$$
\mathrm{P}_{\mathrm{DC}}=\mathrm{e} \sum_{\mathrm{i}}^{\mathrm{N}} \mathrm{G}_{\mathrm{i}} \mathrm{P}_{\mathrm{RF}}^{\mathrm{i}} \eta
$$

Pada persamaan 2 dan 3 di atas setiap daya yang dideteksi akan mengalami perubahan terhadap daya masukan, penguatan dan jarak yang dinyatakan oleh formula Friis sebesar [5]:

$$
P_{r}=\frac{G_{t} G_{r} \lambda^{2} P_{t}}{(4 \pi d)^{2}}
$$

Model penyearah energi RF selalu mengikuti perkembangan sesuai kebutuhan dan pencapaiannya di mana salah satunya adalah penyearah model Dickson (Dickson Models) yang digambarkan sebagai berikut:

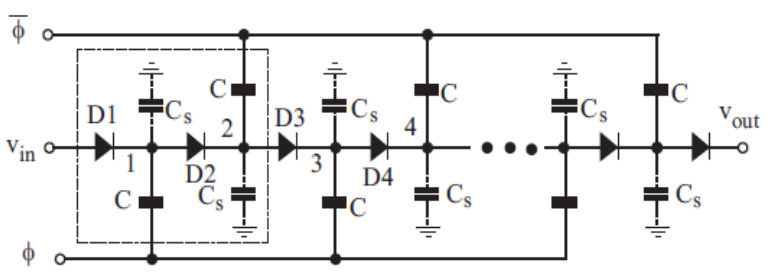

Gambar 2. Model Rangkaian Penyearah Bertingkat [1].

Dasar rangkaian yang dibangun seperti Gambar 2 di atas terdiri dari beberapa rangkaian clamper yang tersusun secara bertingkat dan clock eksternal $\varphi, \bar{\varphi}$ sebagai pengatur dan penggerak sinyal penyearahan yang dinyatakan sebesar;

$$
\mathrm{V}_{\text {out }}=\mathrm{n}\left(\mathrm{V}_{\text {in }}-\mathrm{V}_{\mathrm{T}}\right)
$$

Jika $\mathrm{n}$ tingkatan penyearah dan tegangan ripple $\Delta \mathrm{v}(\mathrm{n})$ diperhitungkan, maka Persamaan 5 menjadi sebesar:

$$
\mathrm{V}_{\text {out }}\left(\mathrm{n}, \mathrm{V}_{\text {in }}\right)=2^{\mathrm{n}} \mathrm{V}_{\text {in }}-\Delta \mathrm{v}(\mathrm{n})
$$

\section{Perancangan Sistem}

Gambaran blok sistem yang dirancang yaitu sebagai berikut:

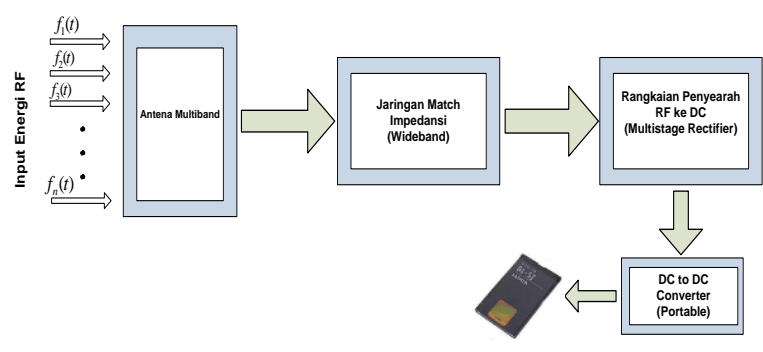

Gambar 3. Blok Sistem Perancangan.

Model penyearah yang dirancang adalah modifikasi model penyearah Dickson di mana pada sisi konstruksi rangkaian dasarnya diterapkan beberapa rangkaian pengganda tegangan yang disusun bertingkat sesuai hasil pengembangan modifikasi ditunjukan berikut ini [6], [7]:

$$
\mathrm{V}_{\text {out }}\left(\mathrm{n}, \mathrm{V}_{\mathrm{RF}}\right)=2^{\mathrm{n}} \mathrm{V}_{\mathrm{RF}}-\left[\frac{\mathrm{I}_{\mathrm{L}}}{\mathrm{f} \times \mathrm{C}}\left(\frac{2}{3} \mathrm{n}^{3}+\frac{1}{2} \mathrm{n}^{2}-\frac{1}{6} \mathrm{n}\right)\right]
$$

Sedangkan secara keseluruhan sistemnya dapat dimodelkan sebagai berikut:

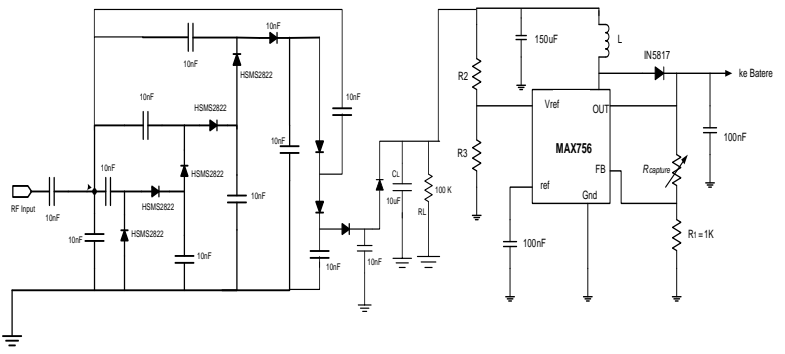

Gambar 4. Rangkaian Penyearah RF-DC. 
Untuk menaikan tegangan keluaran penyearah ke level tegangan catuan perangkat telepon seluler yang akan dicatu, maka digunakan metoda pelacakan tegangan maksimum melalui penentuan variabel resistansi $\Delta \mathrm{R}_{\text {(Capture) }}$ pada rangkaian $D C$ to $D C$ Converter yang nilainya ditentukan sebesar:

$$
\Delta \mathrm{R}_{(\text {Capture })}=\left[\frac{\mathrm{v}_{\text {out }}}{\mathrm{v}_{\text {ref }}}-1\right] \times \mathrm{R}_{1}
$$
sebesar:

Sedangkan tegangan keluaran $\mathrm{V}_{\text {out }}$ sistem diperoleh

$$
\mathrm{V}_{\text {out }}=\frac{\mathrm{V}_{\text {out }}\left(\mathrm{n}, \mathrm{V}_{\mathrm{RF}}\right)}{1-\mathrm{D}}
$$

Model simulasi sistem penyearah energi RF bertingkat multi frekuensi ditunjukkan seperti Gambar 5 berikut ini:

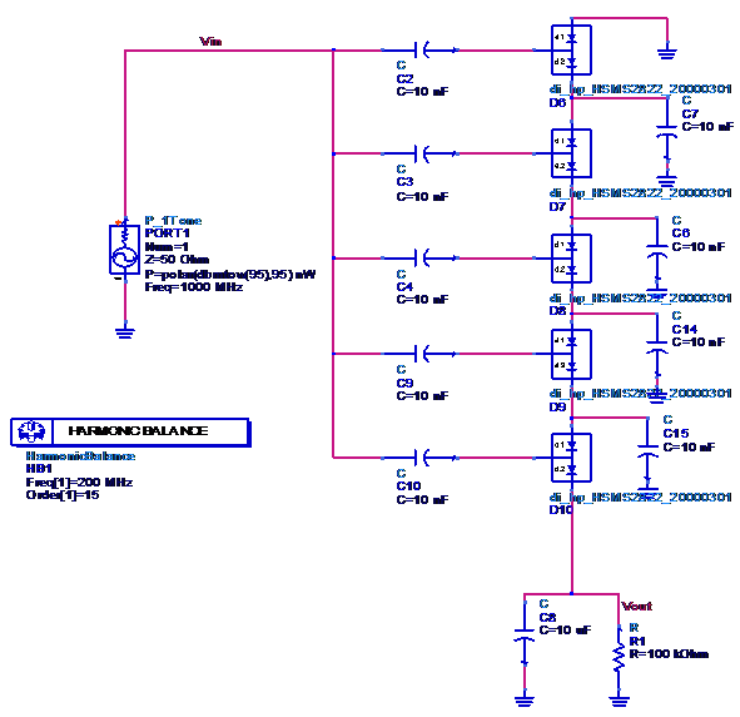

Gambar 5. Simulasi Rangkaian Penyearah.

Hasil simulasinya ditunjukan sebagai berikut:

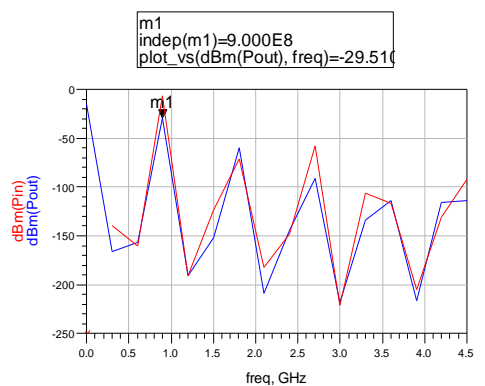

(a)

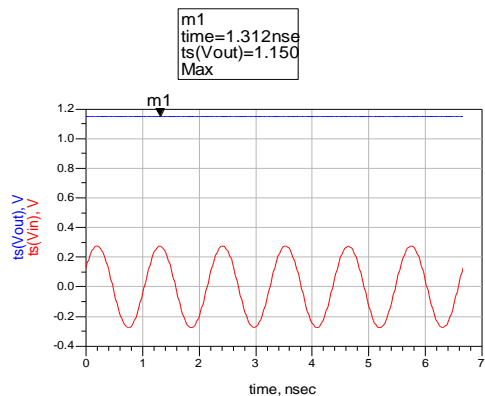

(b)

\section{Pengujian dan Pengukuran}

Pengujian sistem dilakukan untuk memperoleh unjuk kerja sistem melalui tahapan pendekatan teoritis, simulasi dan pengukuran perangkat terkait dengan daya yang akan dicapai. Ilustrasi dari data hasil pengujiannya dapat digambarkan sebagai berikut:

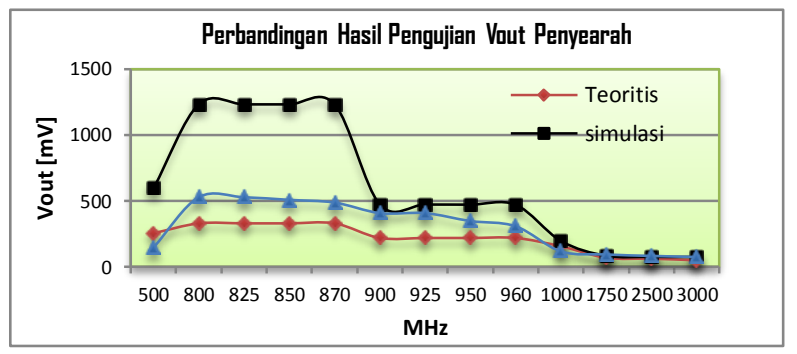

(a)

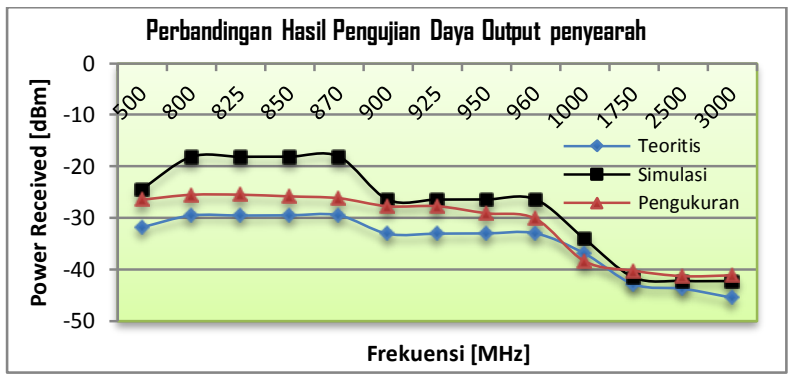

(b)

Gambar 7. Kurva Karakteristik Kinerja Penyearah Regulator Penaik Tegangan, (a) Tegangan, (b) Daya.

\section{A. Regulator Penaik Tegangan}

Regulator penaik tegangan digunakan untuk meningkatkan tegangan hasil penyearahan ke level tegangan catuan sesuai tegangan kerja perangkat telepon seluler yaitu sebesar 3,7 V. Untuk memastikan kualitas kinerja rangkaian ini, maka dilakukan pengujian di dalam ruangan dan luar ruangan sehingga hasilnya diperoleh sebagai berikut:

TABEL 1

\begin{tabular}{|c|c|c|c|}
\hline \multicolumn{2}{|c|}{ Sumber Energi RF } & \multicolumn{2}{|c|}{ Posisi Jarak $(d)=5 \mathrm{~m}$} \\
\hline $\begin{array}{c}\text { Pr } \\
{[\mathbf{d B m}]}\end{array}$ & $\begin{array}{c}\text { Frekuensi } \\
{[\mathrm{MHz}]}\end{array}$ & $\begin{array}{l}\text { Vout } \\
\text { [Volt] }\end{array}$ & $\begin{array}{c}\text { Kondisi Batere } \\
\text { Seluler }\end{array}$ \\
\hline \multirow{11}{*}{+40} & 500 & 0,74 & Tidak mengisi \\
\hline & 825 & 4,47 & Charging \\
\hline & 850 & 4,45 & Charging \\
\hline & 870 & 4,27 & Charging \\
\hline & 925 & 4,10 & Charging \\
\hline & 950 & 3,85 & Charging \\
\hline & 960 & 3,81 & Charging \\
\hline & 1000 & 0,50 & Tidak mengisi \\
\hline & 1750 & 0,20 & Tidak mengisi \\
\hline & 2500 & 0,08 & Tidak mengisi \\
\hline & 3000 & 0,03 & Tidak mengisi \\
\hline
\end{tabular}

HASIL PENGUJIAN DALAM RUANGAN

Gambar 6. (a) Daya dan, (b) Tegangan Output Penyearah. 
TABEL 2

HASIL PENGUJIAN LUAR RUANGAN

\begin{tabular}{|c|c|c|c|}
\hline $\begin{array}{c}\text { Jarak } \\
\text { pengukuran } \\
\text { [meter] }\end{array}$ & $\begin{array}{c}\text { Tegangan } \\
\text { Output } \\
\text { [Volt] }\end{array}$ & $\begin{array}{c}\text { Frekuensi yang } \\
\text { terdeteksi } \\
\text { [MHz] }\end{array}$ & $\begin{array}{c}\text { Kondisi } \\
\text { Batere }\end{array}$ \\
\hline 1 & 4,5 & $\begin{array}{c}950,5 \\
\text { (kanal 52) }\end{array}$ & Charging \\
\hline 2 & 4,3 & $\begin{array}{c}950,5 \\
\text { (kanal 52) }\end{array}$ & Charging \\
\hline 3 & 4,1 & $\begin{array}{c}950,5 \\
\text { (kanal 52) }\end{array}$ & Charging \\
\hline 4 & 3,9 & $\begin{array}{c}950,5 \\
\text { (kanal 52) }\end{array}$ & Charging \\
\hline 5 & 3,8 & $\begin{array}{c}950,5 \\
\text { (kanal 52) }\end{array}$ & Charging \\
\hline 5,5 & 2,9 & $\begin{array}{c}950,5 \\
\text { (kanal 52) }\end{array}$ & $\begin{array}{c}\text { Tidak } \\
\text { mengisi }\end{array}$ \\
\hline
\end{tabular}

\section{B. Efesiensi Konversi Daya}

Efesiensi Konversi Daya ini dapat menentukan besar kecilnya daya dan tegangan yang dihasilkan oleh sistem berkaitan dengan kemampuannya dalam mencatu energi ke batere ponsel. Hasilnya diperoleh sebagai berikut:

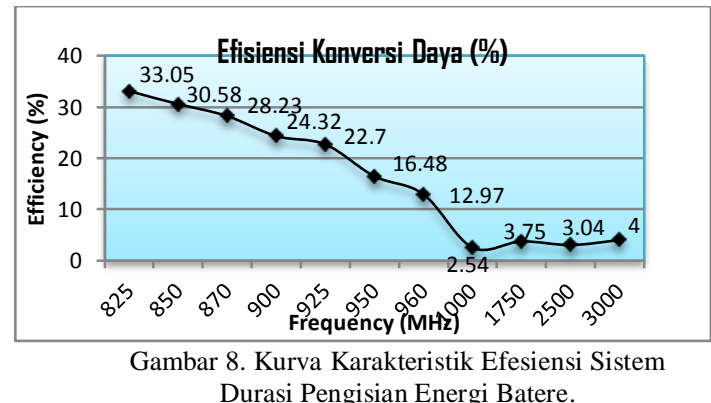

\section{Durasi Pengisian Energi Batere}

Data hasil pengujian durasi waktu pengisiannya di dalam dan di luar ruangan disajikan pada Tabel 3 dan Tabel 4 sebagai berikut:

TABEL 3

PENGUJIAN DALAM RUANGAN

\begin{tabular}{|c|c|l|l|}
\hline $\begin{array}{c}\text { Frekuensi } \\
{[\mathbf{M H z}]}\end{array}$ & $\begin{array}{c}\text { Vout } \\
{[\text { Volt }]}\end{array}$ & $\begin{array}{c}\text { Pout } \\
{[\mathbf{m W}]}\end{array}$ & Durasi Pengisian \\
\hline 825 & 4,47 & 894 & 4 jam 10 menit \\
\hline 850 & 4,45 & 890 & 4 jam 26 menit \\
\hline 870 & 4,27 & 854 & 4 jam 39 menit \\
\hline 925 & 4,10 & 820 & 4 jam 47 menit \\
\hline 950 & 3,85 & 770 & 5 jam 14 menit \\
\hline 960 & 3,81 & 762 & 5 jam 35 menit \\
\hline
\end{tabular}

TABEL 4.

PENGuJian Luar RuANGaN

\begin{tabular}{|c|c|c|c|}
\hline $\begin{array}{c}\text { Frekuensi } \\
{[\mathbf{M H z}]}\end{array}$ & $\begin{array}{c}\text { Vout } \\
{[\text { Volt }]}\end{array}$ & $\begin{array}{c}\text { Pout } \\
{[\mathbf{m W}]}\end{array}$ & Durasi Pengisian \\
\hline 825 & 4,50 & 411 & 9 jam 16 menit \\
\hline 850 & 4,30 & 387 & 9 jam 52 menit \\
\hline 870 & 4,10 & 372 & 10 jam 12 menit \\
\hline 925 & 3,90 & 353 & 10 jam 46 menit \\
\hline 950 & 3,80 & 342 & 11 jam 04 menit \\
\hline 960 & 3,50 & 0 & Tidak mengisi \\
\hline$>960$ & $<3,00$ & 0 & Tidak mengisi \\
\hline
\end{tabular}

Pengujian langsung di lapangan sangat penting untuk mengetahui sekaligus menentukan kualitas kerja sistem yang dirancang secara keseluruhan. Sistem pengukurannya ditunjukkan pada Gambar 9 berikut ini:
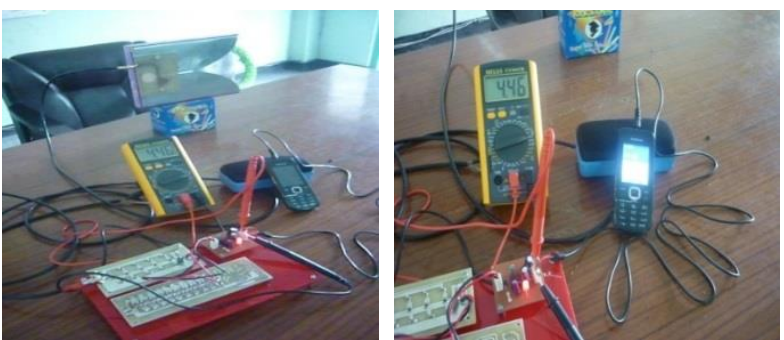

Gambar 9. Pengujian Sistem.

\section{KESIMPULAN}

Modifikasi rangkaian penyearah energi RF ke DC bertingkat multi frekuensi melalui pendekatan Model Dickson yang telah menghasilkan model rangkaian yang mudah diimplementasikan ternyata dapat memberikan kontribusi dalam mewujudkan sebuah perangkat pengisian energi listrik secara nirkabel. Perangkat ini menghasilkan nilai efesiensi konversi daya sebesar 12$33 \%$ dengan faktor ripple secara stabil dicapai di kisaran $0,01 \%$ pada rentang frekuensi $825-960 \mathrm{MHz}$ pada jarak 5 meter dari sumber energi RF yang menghasilkan durasi waktu pengisian sebesar 4 jam sampai dengan 11 jam untuk kondisi di dalam dan di luar ruangan. Kenyataan ini menunjukkan salah satu solusi menjanjikan untuk masa depan terkait dengan pemanfaatan energi terbarukan dalam mengatasi krisis energi ke depan yaitu dengan cara menangkap berbagai sumber energi RF untuk dijadikan sumber energi baru.

\section{UCAPAN TERIMA KaSIH}

Penulis mengucapkan terima kasih sebesarbesarnya kepada Kaprodi Teknik Elektro Fakultas Pascasarjana Universitas Telkom, Prodi Teknik Elektro UNIKOM dan Prodi Teknik Elektro Universitas Kebangsaan Bandung yang telah memberikan kesempatan dan fasilitas untuk menyelesaikan penelitian ini sampai selesai.

\section{DAFTAR PUSTAKA}

[1] D. Pavone, A. Buonanno, M. D. Urso, and F. D. Corte,'Design considerations for radio frequency energy harvesting devices", Progress In Electromagnetics Research B, vol. 45, pp. 19-35, 2012

[2] D. S. Liu, F. B. Li, X. C. Zou, Y. Liu, X. M. Hui, and X. F. Ta,"New analysis and design of a RF rectifier for RFID and implantable devices", Sensor, vol. 11, issue 7, pp. 6494-6508, 2011.

[3] P. Nintanavongsa, U. Muncuk, D. R. Lewis, and K R.Chowdhury, "Design optimization and implementation for RF energy harvesting circuits", IEEE Journal On Emerging and Selected Topics In Circuits and System, vol. 2, no. 1, pp. 24-33, March 2012.

[4] T. S. Rappaport, Wireless Communications Principles and Practice, Second Edition, Prentice Hall PTR, 2002, pp. 107-113.

[5] N. M. Din , C. K. Chakrabarty , A. B. Ismail, K. K. A. Devi, and W. Y. Chen, "Design of RF Energy Harvesting System For Energizing Low Power Devices", Progress In Electromagnetics Research, vol. 132, pp. 49-69, 2012

[6] A. Toudeshki, N. Mariun, H. Hizam, and N. I. A. Wahab, "Development of a new cascade voltage-doubler for voltage multiplication", Chinese Journal of Engineering, vol. 2014, 2014 
[7] A. Sivaramakrishnan and K. J. Jegadishkumar, "A highly efficient power management system for charging mobile phones using RF energy harvesting", International Journal of
Information Technology Convergence and Services (IJITCS), vol.1, no. 5, pp. 21-30, Oct. 2011. 